\title{
Research Based Learning (RBL): How to Improve Critical Thinking Skills?
}

Tri Saptuti Susiani ${ }^{*}$, Moh Salimi, and Ratna Hidayah

Primary Teacher Education, Universitas Sebelas Maret, 57126 Surakarta, Indonesia

\begin{abstract}
Critical thinking is a part of the 21th century necessary skills trained to future teachers. Research-based learning (RBL) presents as an alternative learning model that can develop the critical thinking skills. This study aims at describing the effect of the implementation of the research-based Learning ( $R B L)$ to develop future teachers' critical thinking skills. Qualitative approach was used in this classroom research. The participants in this study consisted of 106 future teachers. Data were collected using observation and test. The results of the research indicate that the implementation research-based learning (RBL) can develop critical thinking skills. It is proved by the fact that the students were able to show their interpretation, analysis, evaluation, inference and explanation abilities. Meanwhile, aspect of self- regulation ability has not yet been able to be found. This research were used to make more sure previous research that implementation of the RBL can improve the quality learning process and make positive changes for the students in the intellectual and emotional. This research provides a different learning experience which can develop critical thinking skill.
\end{abstract}

Keywords : Research Based Learning (RBL), Critical Thinking Skill

* Corresponding author: trisaptuti@staff.uns.ac.id 


\section{Introduction}

Educational Institution for Education Workforce (Lembaga Pendidikan Tenaga Kependidikan, or LPTK) should be able to provide qualified teachers in ccordance with the 21 st century demands. According to National Research Counccil, individuals need to possess competencies in 5 main skills, such as: adaptability; complex communication skills; problem-solving skills; self-management and self-development; and systems thinking. [1] In addition, other skills required to be improved in education to cope with the 21 st century challenge involve work ethic, collaboration, good communication, social responsibility, critical thinking and problem solving. Frydenberg \& Andone, point out that to deal with learning in the 21 st century, every individual should have critical thinking skills, digital literacy knowledge and skills, information literacy, media literacy, as well as information and communication technology skills. [2] To create human resources with critical thinking, problem solving, communication skills and technology literacy requires adequate education and learning through the 21 st century education. [3] The improvement of critical thinking skills have not yet been the main focus in lectures. To train students to improve their critical thinking skills, a lecturer should apply a teaching method which allows them to respond to a phenomenon.

Research-based learning is a learning model which is associated with such activities as analyzing, synthesizing, and evaluating, and enables learners and lecturers to improve their assimilation and application of knowledge. The research-based learning is conducted under constructivism which covers four aspects: learning which constructs students' understanding, learning through developing prior knowledge, learning which involves social interaction process, and meaningful learning which is achieved through real-world experience. Research is an important means of enhancing learning quality. The research components include background, procedures, implementation, research results and discussion, and publication of research results. [4] Research- based learning is a system of instruction which used an authentic - learning, problem - solving, cooperative learning, hands on, and inquiry discovery approach, guided by a constructivist philosophy. Its usefulness had been recognized for many decades but "research in classroom" had not been adopted as a teaching method by many. [5] Research-based learning involves interdisciplinary collaborative research on university students in the learning, meaning that there is a relationship between their learning experience at class and new invention in research. RBL encourages students' active participation in the learning. RBL some learners' competencies include: 1) strong understanding of basic concept and methodology, 2) problem solving in creative, logical, and systematical manners, and 3) scientific attitude which covers respect for evidence, honesty, open-mindedness. [6] Learners are expected to have communication skills, competent technique and analysis to adapt, collaborative work, competition. In reference to such explanation, it follows that RBL is alearning model which integrates research in learning process to construct knowledge by formulating hypotheses, collecting data, analyzing making conclusion, and writing a report. The RBL model gives university students opportunities to learn and construct knowledge from such research procedures as finding information, formulating hypotheses, collecting data, analyzing, making conclusion, and writing a report. The procedures of RBL in a learning: (1) formulating a general question; (2) overview of research-literature; (3) defining the question; (4) planning research activities, clarifying methods/ methodologies; (5) undertaking investigation, analyzing data; (6) interpretation and consideration of results; (7) report and presentation of results. [7]

Critical thinking is defined as the ability to think logically, reflectively, systematically, and productively, applied in judging a situation to make appropriate consideration and 
decision. "Critical thinking is a process of making reasoned judgments based on the consideration

\section{Method}

The participants in this study consisted of 106 students at Pre- Service Teacher Training and Education.Qualitative method was employed in the present research. The research belongs to classroom research due to its orientation of developing quality of educational practices, or of improving educators' skills at class by examining theory-practice in education, evaluating, and applying in educational institutions). Three phases in observation cycle in classroom research according to are: planning meeting, classroom observation, and feedback discussion. ${ }^{[15]}$ Data in the research were collected using observation and test. Instruments used in observation were observation sheets and question sheets. Meanwhile, instruments to assess critical thinking were formulated based on main aspects including interpretation, analysis, evaluation, inference, explanation, and self-regulation. Data analysis techniques used in this research that is done continuously for data collection continued until the end of the study. Data analysis in this research include; data collection, data reduction, the presentation of the data and make conclusions.

\section{Result and Discussion}

RBL was implemented in the course lecture of Integrated Thematic Curriculum Development. The procedures of RBL implemented in the learning were adopted from Peter Tremp's theory, including: formulating a general question; overview of researchliterature; defining the question; planning research activities, clarifying methods/ methodologies; undertaking investigation, analyzing data; interpretation and consideration of results; report and presentation of results. First, the stage of formulating a general question, a topic, or a problem on the nature of learning and integrated learning, and the implementation in primary schools was given to the students. The students at this stage had not recognized the concepts of learning and integrated learning. Next, at the stage of overview of research-literature, students were asked to discuss in groups to examine materials of integrated learning from any references and literatures. After they discussed the concepts as well as various types of integrated learning, questions related to the implementation of integrated learning in primary school arose. Then, at the stage of defining the question, students made temporary hypotheses on the implementation of integrated learning in primary schools. in order to reveal the hypotheses, they were required to conduct a research, and therefore they moved on to the stage of planning research activities, clarifying methods/ methodologies. At the stage, they planned and prepared an investigation to analyze the implementation of integrated learning in primary schools, and focused on the Lesson Plans and the implementation itself by primary school teachers. They discussed in groups and constructed instruments used to observe both Lesson Plans and the implementation. They developed instruments from aspects of integrated learning. Then, at the stage of undertaking investigation and analyzing data, students did investigations by making observation in a primary school. The first investigation was done by making observation on the Lesson Plans of integrated learning constructed by a primary school teacher, while the second one on the implementation of integrated learning in the primary school. At the stage of interpretation and consideration of results, they were asked to analyze their observation results on the Lesson Plans and the implementation of 
integrated learning. Finally, at the stage of report and presentation of results, students reported their research results and analysis in a presentation.

Aspects of critical thinking presented in the research included: interpretation, analysis, evaluation, inference, explanation, and self-regulation. Test results, such aspects of critical thinking as interpretation, analysis, evaluation, inference, and explanation were identified, while aspect of self-regulation was not.

Table 1. Test Results of Critical Thinking

\begin{tabular}{|c|l|c|c|}
\hline No & \multicolumn{1}{|c|}{$\begin{array}{c}\text { Aspect of Critical } \\
\text { Thinking }\end{array}$} & Total & $\begin{array}{c}\text { Percentage } \\
(\mathbf{\%})\end{array}$ \\
\hline 1 & Interpretation & 106 & 100 \\
\hline 2 & Analysis & 75 & 70.75 \\
\hline 3 & Evaluation & 100 & 94.34 \\
\hline 4 & Inference & 32 & 30.19 \\
\hline 5 & Explanation & 71 & 66.98 \\
\hline 6 & Self- regulation & 0 & 0 \\
\hline
\end{tabular}

The observation showed similar results to the test results. Such aspects of critical thinking as interpretation, analysis, evaluation, inference, and explanation were seen, while aspect of self-regulation was not.

The observation showed similar results to the test results. Such aspects of critical thinking as interpretation, analysis, evaluation, inference, and explanation were seen, while aspect of self-regulation was not. To find out aspect of interpretation ability through test, students were asked to answer a question related to the given case: "What did the teacher do before starting the lesson?" All students made correct answer. Based on observation, the aspect of interpretation ability was found in students in each stage of the implemented research-based learning. To find out the aspect of analysis ability, students were asked to answer a question related to the case of learning, "Why does a teacher need to prepare students' worksheets?" 75 students answered correctly. Based on observation, the aspect of analysis skill was found in students in each stage of the implemented research-based learning. To find out the aspect of evaluation ability, students were asked to answer a question related to the case of learning, "What should a teacher do when playing video on environment?" 100 students were able to make correct answer. Based on observations, the aspect of evaluation ability was also seen at the stage of planning research activities, clarifying methods/ methodologie, undertaking. Find out aspect of inference ability, students were asked to answer a question "What should the teacher and students do after break time?" 32 students made correct answer. Phase of report and presentation of results, the inference ability was seen when students presented their research report and gave solutions each other. Students' explanation ability was seen when students were asked to narrate media and their use by teacher in the presented case of learning. The observation results indicate that the explanation ability emerged at the stage of interpretation and consideration of results when students had second discussion about the implementation of integrated learning. At the stage of report and presentation of results, the explanation ability was seen when students explained their written research report. Self-regulation refers to an ability to control and manage individual self both when thinking and acting.

Based on observation and test results, the implementation of RBL model was proved to be able to improv students' critical thinking skills, particularly on the aspects of interpretation, analysis, evaluation, inference, and explanation. Implementation of the RBL is a model that integrates research with learning. Learning that make students active scientific measures. By implementing the scientific method are able to develop critical thinking abilities of students. Research-based learning, interesting discussion and cause gain insight in learning how students can make a design research. ${ }^{[16]}$ Research-based 
learning have pointed to the need to develop an enthusiasm for critical enquiry, resourcefulness and creative solutions in undergraduate students. ${ }^{[17]}$ The RBL model gives opportunities for students to actively participate in the learning. Through research experience, they are expected to implement collaborative learning during the research and the obtained knowledge. Therefore, the RBL model is useful to develop inquiry skills. Students are given chance to learn not only from lecturer's materials, but also from practice of research involving searching for literature, constructing hypotheses, collecting data, analyzing/ testing data, and drawing conclusion. RBL used for the exercise provides students with an opportunity to practice their metacognitive abilities and foster critical thinking, abilities to make predictions, propose causative factors, and present constructive arguments. ${ }^{[18]}$ This is done/measured via/through oral presentations and final reports which all are the core components of any scientific research. Critical thinking nowadays is required to be mastered by university students. The development on science and technology will rapidly lead to the provision of information, either the source or the essence. In order to be able to use the information well, evaluation on data and source of information is required. The evaluation ability and decision making to use accurate information requires critical thinking. Procedures of RBL enable to individuals to equip with deductive, inductive, reflective, critical, and creative thinking abilities. With such abilities, one can deal with more complex life. Students can have critical thinking and problem solving skills in critical manners. In addition, critical thinking is one of initial factors of emergence of creativity, which develops due to observation of a phenomena or problem. The implementation of RBL, students not only receive information from the lecturer alone. This RBL allow students to participate in the plot and investigated a problem. Characteristics of the rbl more refers to the flow of education kontruktivistik, where learning is an active process of learning to find and build knowledge. Active processes is not only mentally but also physically. Kontruktivistik instruction can help the development of skills to think through problem-based teaching style openeded used teacher. Step-by-step problem-solving activities there are RBL. ${ }^{[19]}$ Activity breakdown not only can develop critical thinking skills, but can also deepen understanding of students against the concepts studied. ${ }^{[20]}$ When students are involved in solving problems, students felt having a role in the effort to find a solution and need to take real action.

\section{Conclusion}

\subsection{Acknowledgement}

The research results conclude that RBL model can be implemented in the learning of future primary school teachers in such stages as formulating a general question; overview of research-literature; defining the question; planning research activities, clarifying methods/methodologies; undertaking investigation, analyzing data; interpretation and consideration of results; report and presentation of results. Its implementation enables to develop their critical thinking skills. It is revealed from the emergence of abilities of such aspects as interpretation, analysis, evaluation, inference, and explanation. The selfregulation ability, however, was not found. Test and observation were employed in the research. The future research is expected to continue the present research with technique of clinical interview. 


\section{References}

1. J.A. Koenig, Rapporteur, Assessing 21st century skills: summary of a workshop (The National Academies Press, Washington DC, 2011)

2. M. Frydenberg, D. Andone. IEEE. (2011)

3. M. Salimi, Guru yang efektif dan pengajaran yang efektif dalam rangka menyongsong generasi emas 2045: Sebuah Kajian Awal. (Universitas PGRI Semarang Press, Semarang, 2016)

4.D. T.Widayati, D. Luknanto, E. Rahayuningsih. Pedoman umum pembelajaran berbasis riset (UGM. Yogyakarta, 2010).

5. S. Poonpan, S. Siriphan, Indicators of research-based learning instructional process: a case study of best practice in a primary school, (Bangkok, Faculty of Education, Chulalongkorn University Phaya Thai, 2001

6. P. Arifin, Makalah seminar nasional research based learning, (ITB, Bandung, 2010)

7.P. Tremp, Research-based teaching and learning A LERU project (University of Zurich, Munich, 2010)

8. P. A. Facione, CA Sánchez, NC Facione, J Gainen, JGE, 44 (2010)

9. P. C. Seifert, AORN, 91 (2010).

10. P. Facione, Critical thinking: what it is and why it counts (California Academic Press, Millbrae, 2013)

11. D. Rosyada, Pembelajaran perbasis pelitian. [http://www.uinjkt.ac.id/pembelajaran-berbasis-penelitian/] (2016)

12. M. Fikri, Research based learning, asah kemampuan praktis mahasiswa ITB. [https://www.itb.ac.id/news/read/3211/home/research-based-learning-asahkemampuan-praktis-mahasiswa-itb] (2011)

13. K. C. Suryandari, Pedagogia, 16, 2 (2013)

14. Buschor, C. Bieri, Kamm, Esther, ERPP, 14, 3 (2015)

15. D. Hopkins, A teacher's guide to classroom research fourth edition (Open University Press, New York, 2008)

16. Ellen Bastiaens, Three Educational Models for Positioning the Maastricht Research-Based Learning Programme (Springer, Maastricht, 2017)

17. P. Guinness, JGHE, 36, 3 (2012)

18. A. Al- Maktoumi. et.al, JGHE, 40 (2016)

19.D. Mujis, D. Reynolds, Effective Teaching (Sage Publications, London, 2008).

20.R. Killen, Effective Teaching Strategies: Lessons From Research and Practice (Cencage Learning, Victoria, 2009) 